\title{
THE PRESIDENT / LE PRESIDENT
}

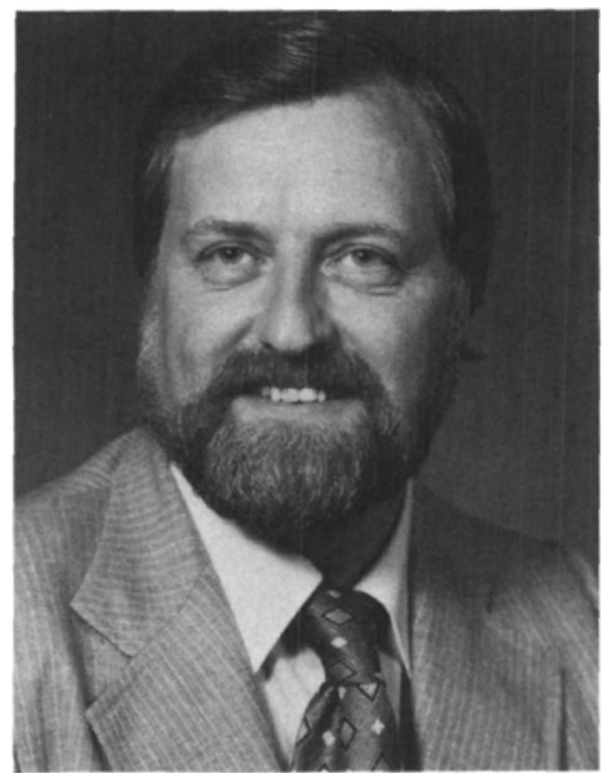

John Bryan Reed Parker

M.B., B.S., C.R.C.P.(C)

Dr. J.B.R. Parker of Saskatoon was installed as President of The Canadian Anaesthetists' Society at the Annual Meeting at Toronto in June, 1980.

Dr. Parker qualified M.B., B.S., (London) from St. Bartholmew's Hospital Medical School in 1960. He trained in Anaesthesia in the department of Anaesthesia and Clinical Measurement at Westminster Hospital, London, from 1962 to 1965 and as Registrar, Bournemouth and East Dorset Hospital Group 1965 to 1967.

He emigrated to Canada in 1967, and engaged in General Practise and Anaesthesia in Prince Albert, Saskatchewan, After obtaining the Certification in Anaesthesia of the Royal College of Physicians and Surgeons of Canada in 1970 he joined the Department of Anaesthesia of the Saskatoon City Hospital in 1971 and is presently the Chief of that department and Clinical Associate Professor of Anaesthesia at The University of Saskatchewan.

From 1972 to 1977 Dr. Parker was Chairman of the Anaesthetic and Operative Death Review Committee of the Saskatchewan College of Physicians and Surgeons. He has been Chairman of the Saskatchewan Division of The Canadian
Le docteur J.B.R. Parker de Saskatoon a assumé la présidence de la Société Canadienne des Anesthésistes au cours du congrès annuel tenu à Toronto, en juin 1980.

Le docteur Parker est diplồmé en médecine (M.B., B.S.) de l'école de médecine de l'Hôpital St-Bartholomew (Londres) en 1960. Il a poursuivi sa formation d'anesthésie dans les départements d'anesthésie et de biométrie clinique à l'Hôpital Westminster de Londres de 1962 à 1965 . De 1965 à 1967, il agit à titre de registrat à Bournemouth et dans le groupe hospitalier de East Dorset.

Il émigre au Canada en 1967 et exerce en médecine générale et anesthésie ầ Prince Albert, Saskatchewan. Il obtient la certification en anesthésie du Collège Royal des Médecins et Chirurgiens du Canada en 1970 et dès 197I, il devient membre du département d'anesthésie de l'Hốpital Civique de Saskatoon, département qu'il dirige maintenant. Il est Professeur Adjoint d'Anesthésie à l'Universitẻ de Saskatchewan.

De 1972 à 1977, le docteur Parker a siégè à titre de président du comité d'étude des mortalités en relation avec l'anesthésie du Collège des Médecins et Chirurgiens de la Saskatchewan. Depuis 1975, il est président de la division de la Sas- 
Anaesthetist's Society and of the Section of Anaesthesia of The Saskatchewan Medical Association since 1975. He was appointed to the Council of the Canadian Anaesthetists' Society as representative of the Saskatchewan Division in 1975, and as a representative of Council on the Executive Committee in 1977. He was elected 2nd Vice-President in 1978, and Ist VicePresident in 1979.

Dr. Parker was married to Dr. Zillah Russell in 1960. Dr. Zillah Parker practises Psychiatry in Saskatoon. They have three daughters and live on a farm near Saskatoon, where they raise hay and a variety of animals and birds. Dr. Parker's other interests include classical music, botany, sailing, flying, mountaineering, skiing and electronics. katchewan de la Société Canadienne des Anesthésistes et de la section d'anesthésie de l'Association Médicale de la Saskatchewan. Il était délégué de la division de la Saskatchewan au conseil de la Société Canadienne des Anesthésistes depuis 1975 et à partir de 1977, il a agi à titre de représentant du conseil auprès du bureau de la Société. Il a occupé le poste de deuxième vice-président en 1978 et de premier vice-président en 1979.

Le docteur Parker est marié au docteur Zillah Russell depuis 1960. Celle-ci pratique la psychiatrie à Saskatoon. Ils ont trois filles et vivent sur une ferme près de Saskatoon où ils cultivent du foin et font l'élevage d'un variété des animaux et des oiseaux. Ses intérêts dans la vie ne s'arrêtent pas là et incluent le goût pour la musique classique, la botanique, la navigation à voile, l'aviation, le hicking, le ski et l'électronique. 